\title{
AVALIAÇÃO DO PROCEDIMENTO DE REPOSIÇÃO DE PRÉ-MAXILA EM PACIENTES FISSURADOS LABIOPALATAIS
}

Elaine Peixoto MENDES, Danielle DEL SANTO, João Luiz CARLINI

Dentre as deformidades faciais, as fissuras labiopalatinas ocorrem $1 \mathrm{em}$ cada 600 nascimentos. Pacientes acometidos por esta alteração requerem atendimento multiprofissional ao longo do seu desenvolvimento. $O$ tratamento inicia-se aos 18 meses com queiloplastia e termina aos 18 anos com rinoplastia. Um dos procedimentos cirúrgicos realizados, é a reposição de prémaxila e a colocação de enxertos ósseos no local da fissura, visando prevenir o colapso e a constrição do arco dentário. O Objetivo deste estudo foi avaliar os resultados funcionais da cirurgia de reposição de pré-maxila e seus benefícios. Foram avaliados 65 prontuários, destes 11 pacientes eram portadores de fissuras pré-forame, 57 trans-forame e 2 pós-forame. Sendo que, 27 receberam enxerto de ilíaco, 29 de mento. 43 usaram expansor do tipo Hass e 5 máscara facial para retração da maxila. Apenas 1 foi submetido a expansão cirúrgica de maxila. 32 pacientes apresentaram os caninos irrompidos na radiografia panorâmica pós-cirúrgica. $O$ estudo possibilitou avaliar a validade da reposição de pré-maxila com enxerto ósseo no posicionamento e erupção dos caninos superiores, sendo que uma falha na erupção adequada destes dentes causa importante alteração oclusal. Teve-se resultado satisfatório de $60 \%$ de sucesso em fissurados unilaterais ou bilaterais com fissura pré-forame, pós-forame ou trans-forame.

Palavra-chave: Fissura palatina; Enxerto ósseo; Erupção dentária. 